\title{
Event characteristics and socio-demographic features of rape victims presenting for post exposure prophylasix at the Federal Medical Centre, Owerri Nigeria
}

\author{
*Nwolisa CE., Ofondu E., Ezeogu J., Odinaka K., Adimora O.
}

\begin{abstract}
Objectives: On account of increasing awareness of the need for Post exposure prophylaxis (PEP) and availability of requisite drugs, victims of rape are now presenting at health facilities including ours to access PEP for HIV. This study set to document the socio-demographic features of these victims and the event characteristic of the rape act.
\end{abstract}

Methods: The medical records of patients who presented between January 2009 and December 2013 to the Paediatric infectious diseases clinic of Federal medical Owerri for PEP were reviewed.

Results: One hundred and fifty three patients presented over reviewed period. $148(96.7 \%)$ presented for PEP on account of rape. They consisted of 147 females and 1 male.61 (41.2\%) of victims previously knew and could identify their assailants while $19(12.8 \%)$ of the victims had been previously raped. $32(21.6 \%)$ victims presented on the day of the rape and weapons were used in $27 \%$ of the cases to ensure the victims cooperation. The most common place for the rape act was the assailant's home.None of the victims completed the schedule of follow up visits.

Conclusion: Rape remains the commonest reason for presentation at our centre for PEP. Most victims still present late and are nearly always lost to follow-up after the initiation of PEP.

Keywords: HIV, Rape, Post exposure prophylaxis, Criminal code.

*Corresponding Author: Dr. Nwolisa CE., Email: nwolisaemeka@yahoo.com

Paediatric Infectious diseases unit, Federal Medical Centre, Owerri, Nigeria.

Research Journal of Health Sciences subscribed to terms and conditions of Open Access publication. Articles are distributed under the terms of Creative Commons Licence (CC BY-NC-ND 4.0). (http://creativecommons.org/licences/by-nc-nd/4.0).

http://dx.doi.org/10.4314/wsa.v4i3.3 


\title{
Caractéristiques de l'événement et les caractéristiques socio- démographiques des victimes de viol qui se présentent pour post- exposition prophylasix au Centre médical fédéral, Owerri au Nigeria
}

\author{
*Nwolisa CE., Ofondu E., J. Ezeogu, Odinaka K., Adimora O.
}

\section{Resume}

Objectifs: En raison de la sensibilisation à la nécessité d'une prophylaxie post-exposition (PEP) et la disponibilité des médicaments nécessaires, les victimes de viol sont maintenant présentent dans les établissements de santé, y compris la nôtre pour accéder à PEP pour le VIH. Cette étude visait à documenter les caractéristiques socio-démographiques de ces victimes et la caractéristique de l'événement de l'acte de viol.

Méthodes: Les dossiers médicaux des patients qui ont présenté entre Janvier 2009 et Décembre 2013 pour la pédiatrie clinique des maladies infectieuses de Federal Owerri médicale pour PEP ont été examinés.

Résultats: Cent cinquante-trois patients présentés sur la période examinée. $148(96,7 \%)$ ont présenté pour la PPE en raison du viol. Ils consistaient en 147 femelles et 1 male.61 $(41,2 \%)$ des victimes déjà connu et pourrait identifier leurs agresseurs tandis que $19(12,8 \%)$ des victimes avaient déjà été violées. $32(21,6 \%)$ victimes présentées le jour du viol et des armes ont été utilisées dans $27 \%$ des cas pour assurer la coopération des victimes. L'endroit le plus commun pour l'acte de viol était le home.None de l'agresseur des victimes a complété le calendrier des visites de suivi.

Conclusion: Le viol reste la plus fréquente raison de la présentation à notre centre pour la PPE. La plupart des victimes encore présents en retard et sont presque toujours perdus de vue après le début de la PPE.

Mots clés: VIH, le viol, la prophylaxie post-exposition, le code pénal.

\footnotetext{
*Auteur correspondant: Dr. Nwolisa CE., Email: nwolisaemeka@yahoo.com
}

Paediatric Infectious diseases unit, Federal Medical Centre, Owerri, Nigeria. 


\section{INTRODUCTION}

The definition of rape has changed over the years becoming more encompassing. In its most simplistic form, It is defined as' sexual intercourse or other forms of sexual penetration, initiated by a person against another person without the consent of that person' [1]. The World Health Organization in 2002 defined rape as "physically forced or otherwise coerced penetration even if slight of the vulva or anus, using a penis, other body parts or an object".Under the statutes of the International Criminal Court , the elements to be met for rape to have occurred are 'invasion by the perpetrator of the body of a person by conduct resulting in penetration, however slight, of any part of the body of the victim or of the perpetrator with a sexual organ, or of the anal or genital opening of the victim with any object or any other part of the body.'The invasion must have been committed by force, or by threat of force or coercion, such as that caused by fear of violence, duress, detention, psychological oppression or abuse of power, against such person or another person, or by taking advantage of a coercive environment, or the invasion was committed against a person incapable of giving genuine consent [2].

In Nigeria however the Criminal Code Act defines rape as 'unlawful carnal knowledge of a woman or girl, without her consent, or with her consent, if the consent is obtained by force or by means of false threats or intimidation of any kind, or by fear of harm, or by means of false or fraudulent representation as to the nature of the act, or in case of a married woman, by impersonating her husband.' This definitionhas obvious flaw as demonstrated by Olatunji [3] in his comprehensive review of the Nigerian rape law. It presupposes or presumes that only women can be raped and involves only penile and vaginal sex.It does not make provision for nor does it recognise male rape and it also does not recognise or acknowledge anal sex as a form of rape.

There has lately been increased reportage of rape in the media and several factors have been identified as drivers of the increasing acts of rape. These factors include belief in family honour and sexual purity, ideologies of male sexual entitlement and weak legal sanctions for sexual violence. [4] Several news reports in Nigeria would appear to suggest weak legal sanctions as the dominant factor for rape in the country [5]. Under the present legal statutes in Nigeria, for the offence of rape to be properly established, there must be corroborative evidence which usually comes from eyewitnesses account or medical evidence. The eye witness corroboration under the law strangely requires that such witnesses must have witnessed the actual penetration of the victim's vagina [3]. This obviously makes securing a conviction for rape tough and effectively nullifies the deterrent effect of a conviction. The rising incidence of rape as reported by the news media would therefore tend to suggest that our policies and laws as regards rape are not effective.

Documented impact of rape on the victims in Nigeria include multiple bruises, lacerations and perineal tears [6-7]. Victims of Rape in addition to the physical and psychological torment of the act are also at risk for sexually transmitted diseases. While several infections can be transmitted through rape, HIV appears to be the most significant and distressing giving that there is yet no cure and the attendant stigma. Attempts at preventing HIV infection following rape can be made through the use of post exposure prophylaxis (PEP). Animal models have shown that after initial exposure, HIV replicates within dendritic cells of the skin and mucosa before spreading through lymphatic vessels and developing into a systemic infection.[8]This offers an important window of opportunity to prevent infection.

Giving increasing awareness of PEP and availability of requisite drugs, victims of rape are now presenting at health facilities including ours to access PEP for HIV following rape.

This study set to document the sociodemographic features of these patients and the event characteristic of the rape act.

\section{METHODS}

Study Setting

The Federal medical centre Owerri is a tertiary health facility located in the capital city of Imo state in South-eastern Nigeria. It offers services to clients from Imo state and neighbouring states of Abia, Anambra and Rivers.

The centre has a Comprehensive HIV care and treatment unit for both adult and Paediatric patients. Amongst services offered by the unit is the provision of post exposure prophylaxis (PEP) for rape victims. The PEP services encompass pre-test counselling, HIV screening, post- test counselling, and provision of drugs and subsequent follow up appointments for repeat HIV testing in line with the Nigerian national guideline. 


\section{Study design}

The study involved retrospective analysis of medical records of patients who presented at the unit for PEP services. The medical records of patients 18 years and less who presented over a five year period between January 2009 and December 2013 were reviewed. Information extracted included age, gender, place of rape, time of rape, number of assailants, use of weapons and HIV status of the victim at presentation. Ethical permission for the study was granted by the ethics committee of the hospital.

\section{RESULTS}

One hundred and fifty three patients who were 18years and below presented to the unit for PEP over the reviewed period. Of this number, 148 presented on account of rape. Rape therefore was the reason for presentation of $96.7 \%$ of patients. There were $147(99.3 \%)$ females and $1(0.7 \%)$ male. The age of victims ranged from 2 years to 18 years with a mean of 13.33 years. The age pattern of the rape victims is outlined in Table 1.

Sixty-one (41.2\%) knew their assailant(s). 85(57.4\%) did not know, while information about the assailants of 2 victims were not documented. Meanwhile 32(21.6\%) victims presented on the day of the rape, 73(49.3\%) presented after 24 hours but within $72 \mathrm{hrs}$ of the incident. 43(29.1\%) presented after $72 \mathrm{hrs}$ of the incident.

145(98\%) victims were HIV negative at presentation but $2(1.4 \%)$ were positive. The status of 1 patient at presentation was not documented. 103(69.6\%) victims had never had sexual intercourse previously while $28(18.9 \%)$ had. The medical records for $17(11.5 \%)$ did not indicate if they had ever had sex before the rape incident. While 101(68.2\%) victims had achieved menarche, $47(31.8 \%)$ had not. For $120(81.1 \%)$ victims this was their first incident while $19(12.8 \%)$ had been previously raped. Amongst those previously raped, victims aged between 11-15years accounted for $63.2 \%$ of cases. (Table 1).

In the rape of $67.6 \%$ of victims, no weapons were used while in $27 \%$ a weapon of some sort was used. For $5.4 \%$ of the victims there was no documentation as to whether or not weapons were used in the reviewed medical records. $133(89.9 \%)$ victims had PEP while $15(10.1 \%)$ did not. The most common place for rape as found in the study was the assailant's home closely followed by the bush (Table 11). While the number of assailants who raped the victims ranged from 1 to 5 , In the case $106(71.6 \%)$ victims, there was only one assailant while in the remaining victims, there were more than one assailants. No patient was documented to have completed follow up visits in line with the national guideline.

\section{DISCUSSION}

This study identifies rape as the major reason for seeking post exposure prophylaxis (PEP) in the Paediatric infectious diseases clinic of the Federal medical centre Owerri. 97\% of patients who sought PEP for HIV during the reviewed period were as a result of rape. Other reasons for seeking PEP for HIV were 3(1.9\%) on account of prick from a needle used to inject an HIV infected person and $2(1.3 \%)$ on account of bite from an HIV infected person. While most of the rape victims were females, a case of a male victim was documented unlike several other reports from both Southern and Northern Nigeria [9, $10,11,13]$. The site of assault or penetration in this case was anal. While the preponderance of rape cases involved females, this goes to further confirm the presence of male rape in Nigeria. Amongst the shortcomings pointed out by Olatunji [3] in the Nigeria criminal code, is the non acknowledgement of male rape victims and anal sex not recognised as a form of rape.

The age range of 2years to 18years of the victims was quite wide but the mean age of 13.33 yrs appears close to $12 \mathrm{yrs}$ reported in a study in Jos, North Central Nigeria [11]. Over two thirds of the victims were adolescents. This is in keeping with other studies that have identified and reported the increased risk of rape amongst adolescents $[12,13]$.

Nearly half of the victims knew the rapist or assailant and could identify them. This is less than $62 \%$ and $79.6 \%$ reported respectively in Ile-Ife [10] and Osogbo[14] both in southwest Nigeria. This difference is most likely due to the age of victims in both studies .Both studies involved older patients while our studied population had younger victims who were too young to be effectively expected to identify their assailants.

$69.6 \%$ of our patients had never had sex before the rape. The physical and psychological impact would obviously be traumatic. $12.8 \%$ of the patients in this study had been previously raped. This is lower than $25 \%$ reported by Ashimi and co -workers [15] in a rural tertiary health facility in Northwest, Nigeria. 
The victim's home and the assailant's home accounted for $44.6 \%$ of the sites or locations of the rape act. This pattern is similar to that reported in Ile-Ife [10], Calabar[7]' Ethiopia [16], and Jos [11]. This correlates with the percentage of victims who knew and could identify their assailants. Sadly $2 \%$ of victims were raped in the church by Armed men. The victims were in church to attend night Virgil programmes common with Pentecostal churches. This shows a total lack of respect for the aura and holiness associated with churches or places of worship.

The number of assailants ranged from one to five. Over two thirds of the victims in our study were raped by single assailants, this agrees with most other studies in which single assailants were dominant .[9,15,16] Cases of gang rape which commonly involves three or more assailants occurred in $8.8 \%$ of cases, this is higher than 5.1\% reported in a study in Ethiopia. [16]. Most cases of gang rape in this study involved the use of weapons and were commoner in the course of armed robbery. It is a bit difficult in the context of this study to adduce the reason (s) for this. We can only infer that those capable of violence associated with robberies are capable of anything including rape.

Only $1.4 \%$ of the victims were HIV positive at the time of presentation. This is lower than $5.1 \%$ reported in Ethiopia [16] and none of these patients had been previously diagnosed. In our study, the two victims who were HIV positive were aged 15 and 17 years respectively and had no previous history of sexual intercourse so infection is obviously not on account of unprotected sex.

Weapons were used in $27 \%$ of cases by the assailants to ensure compliance. This is similar to the Ile-Ife [10] report where use of a weapon was documented in $29.6 \%$ of cases but higher than $12.4 \%$ reported in a study in North central Nigeria. [15] The weapons used included guns, knives/machetes and broken bottles. Guns were used in cases that essentially were armed robbery events and the robbers now having cowed the victims proceeded to rape them. The reviewed records indicated none of the victims was shot.

$89.9 \%$ of victims following presentation in our facility had some form of PEP for HIV. This is higher than $29.4 \%$ reported in a Lagos study. This is not surprising giving the increased awareness of our PEP programme and the proactive measures adopted by our hospital to ensure that every client received PEP with minimal stress.

Only $21.6 \%$ of the victims presented to hospital within 24 hours of the incident leaving the majority presenting fairly late. This is in contrast to a report from Ile-Ife [10] where majority of the victims presented within 24 hours. Our figure is also still less than that reported from Osogbo [14] where $40 \%$ presented within 24 hours. Time is of essence because the success of PEP is higher with earlier presentation. Amongst reasons adduced for late presentation is the fear of stigmatisation and in younger children the fear of the threat by the assailant. $49.3 \%$ and $43.2 \%$ of the patients were raped during the day and night respectively. More cases of rape occurring during the day have been reported by several other studies $[10,13,14]$. A plausible explanation given the age of the victims in our study would be that during the day, their parents or caregivers were probably at work or earning an income thereby leaving them vulnerable.

Unfortunately, most of the victims in our study did not or were not brought back for follow up as only in the records of two victims were there evidence of repeat visit but even that did not indicate optimal follow up. Other studies have also reported this pattern. [10,15] The possible reasons as adduced by Ashimi et al would include the 'emotional trauma of the rape, fear of stigmatization and non-appreciation of the need to do this.' The obvious challenge the loss to follow up poses is the inability to access the outcome of the instituted PEP for HIV and any late complications.

\section{CONCLUSION}

This study has shown that rape is the commonest reason for presentation at our centre for PEP. This suggests an increased awareness of the place of PEP in preventing HIV infection after exposure. In spite of this awareness though, victims still presented late and were nearly always lost to follow-up after the initiation of PEP. Increased patient awareness for early presentation and the appreciation of the need for effective follow-up visits is essential for satisfactory PEP Outcome.

Acknowledgement: The authors which to acknowledge the assistance of the medical records unit of the Heart to Heart centre of the Federal medical centre, Owerri.

Conflict of interest: None declared. 


\section{REFERENCES.}

1. Smith, ed. by Merril D. .Encyclopedia of rape. Greenwood Press.2004.pp. 169-170.

2. Jewkes R, Sen P, Garcia-Moreno C. Sexual Violence in; E.G .Krug et al (EDS) . World report on violence and health. Geneva. Switzerland. 2002. WHO.

3. Olatunji A.O. Penetration, corroboration and non consent; examining the Nigerian law of rape and addressing its shortcomings. Univ Ilorin law J. 2012;8: 79-105.

4. WHO. Violence against women. World Health Organization. 2012-11-23.

5. 5.Akinade E, Adewuyi T, Sulaiman A. Sociolegal factors that influence the perpetuation of rape in Nigeria. Social and behavioural sciences. 2010;5:1760-4.

6. Daru P H, Osagie E O, Pam I C, Mutihir J T, Silas O A, Ekwempu C C. Analysis of cases of rape as seen at the Jos University Teaching Hospital, Jos, North Central Nigeria. Niger J ClinPract .2011;14:47-51.

7. Ekabua JE1, Agan TU, Iklaki CU, Ekanem EI, Itam IH, Ogaji DS. Trauma related to sexual assault in Calabar, south eastern Nigeria. Niger J Med. 2006;15:72-4.

8. Center for Disease Control and Prevention. Updated U.S Public health service guidelines for the management of occupational exposures to $\mathrm{HBV}, \mathrm{HCV}$ and HIV and recommendations for postexposure prophylaxis. MMWR 2001; Vol. 50, issue RR-11.

9. Abdulkadir. I, Umar .L.W, Musa.H.H, Musa.S, O y e $n$ i y i. O. A, A y o o 1 a williams.O.M,Okenyi.L. Child sexual abuse: A review of cases seen at General Hospital Suleja, Niger state. Ann Afrmed . 2011;5: 1519.

10. Badejoko OO1, Anyabolu HC2, Badejoko BO3, Ijarotimi AO1, Kuti O1, Adejuyigbe EA Sexual assault in Ile-Ife, Nigeria. .Niger Med J. 2014;55:254-9.

11. Daru PH, Osagie EO, Pam IC, Mutihir JT, Silas OA, Ekwempu CC. Analysis of cases of rape as seen at the Jos university Teaching Hospital, Jos, North central Nigeria. Nig $\mathrm{j}$ clinpract . 2011;14:47-51.

12. Morenike O. Folayan, MorolakeOdetoyinbo, Abigail Harrison, Brandon Brown .Rape in Nigeria: a silent epidemic among adolescents with implications for HIV infection. Sex Transm Infect. $2004 ; 80: 138-41$.

13. Fatimat Akinlusi, HabiruRabiu, TawaOlawepo, AdeniyiAdewunmi, TawaqualitOttun, OluwarotimiAkinola.
Sexual assault in Lagos. A five year retrospective review. BMC women's Health 2014;14:115.

14. Adeleke NA, Olowookere AS, Hassan MB, Komolafe JO, Asekun-Olarinmoye EO. Sexual assault against women at Osogbo Southwestern Nigeria. Niger $\mathrm{J}$ clinPract. 2012;15:190-3.

15. Ashimi AO, Amole TG, Ugwa EA. Reported sexual violence among women and children seen at the Gynaecological emergency unit of a rural tertiary facility, Northwestern Nigeria.

16. Demisew A, Desta H. Sexual assault : Pattern and related complicactioins among cases managed in JImma University Specialised Hospital. Ethiop J Health Sci.2014;1: 13-24. 
Table 1. Socio-demographic of respondents

\begin{tabular}{|c|c|c|}
\hline Variables & Number & Percentage. \\
\hline \multicolumn{3}{|l|}{ Gender } \\
\hline Females & 147 & 99.3 \\
\hline Males & 1 & 0.7 \\
\hline \multicolumn{3}{|l|}{ Age. } \\
\hline 5years and less & 11 & 7.4 \\
\hline 6-10years & 23 & 15.5 \\
\hline 11-15years & 62 & 41.9 \\
\hline 16-18years & 52 & 35.2 \\
\hline \multicolumn{3}{|c|}{ Interval before presentation } \\
\hline Within 24 hours. & 32 & 21.6 \\
\hline Within 72 hours & 73 & 49.3 \\
\hline After $72 \mathrm{hrs}$. & 43 & 29.1 \\
\hline \multicolumn{3}{|c|}{ Previous sexual experience } \\
\hline None before & 103 & 69.6 \\
\hline Yes before & 28 & 18.9 \\
\hline Not stated. & 17 & 11.5 \\
\hline \multicolumn{3}{|l|}{ Previously raped } \\
\hline 5years and less & 1 & 5.2 \\
\hline $6-10 y r e a r s$ & 4 & 21.1 \\
\hline 11-15years & 12 & 63.2 \\
\hline 16-18years & 2 & 10.5 \\
\hline \multicolumn{3}{|l|}{ Time of rape } \\
\hline Day time & 73 & 49.3 \\
\hline Night & 64 & 43.2 \\
\hline Not stated & 11 & 7.4 \\
\hline
\end{tabular}


Table 2. Site of rape

\begin{tabular}{lll}
\hline & & \\
SITE OF RAPE & NUMBER & PERCENTAGE. \\
\hline Home of rapist & 38 & 25.7 \\
Bush & 35 & 23.6 \\
Home of victim & 28 & 18.9 \\
Uncompleted building & 10 & 6.8 \\
Church & 3 & 2 \\
School compound & 4 & 2.7 \\
Inside tricycles & 2 & 1.4 \\
Hotel & 1 & 0.7 \\
Site undocumented & 27 & 18.2 \\
& & \\
\hline Total & 148 & $100 \%$ \\
\hline
\end{tabular}

Table 3. Number of rapist

\begin{tabular}{lll}
\hline $\begin{array}{l}\text { Number of } \\
\text { Assailants }\end{array}$ & Number of victims & percentage \\
\hline 1 & 106 & 71.6 \\
2 & 27 & 18.2 \\
3 & 7 & 4.7 \\
4 & 4 & 2.7 \\
5 & 2 & 1.4 \\
Not stated & 2 & 1.4 \\
\hline Total & 148 & $100 \%$ \\
\hline
\end{tabular}

